\title{
Study Comparing High Dose Palanosetron 0.075mg with Low Dose Palanosetron 0.05mg Plus 4mg Dexamethasone as Adjuvant for Prevention of Post-Operative Nausea and Vomiting in Laproscopic Hysterectomies - A Double Blinded Study
}

\author{
Payal Jain ${ }^{1}$, Pallavi Ahluwalia ${ }^{2}$, Amit Ahluwalia ${ }^{3}$, Ravi Jain ${ }^{4}$ \\ ${ }^{1}$ Assistant Professor, Department of Anaesthesia, Teerthanker Mahaveer Medical College, and research Centre, Moradabad, ${ }^{2}$ Professor, Department of \\ Anaesthesia, Teerthanker Mahaveer Medical College, and research centre, Moradabad, ${ }^{3}$ Consultant, Department of Orthopedics, Kothiwal Dental College, \\ Moradabad, ${ }^{4}$ Consultant, Radiodiagnosis, Cosmos Hospital, Moradabad.
}

\section{Abstract}

Background: Post op nausea and vomiting is one of the most distressful complications after surgical procedure. The complex of same is very complex but laproscopic surgeries are one of the major reasons. Various agents have been found helpful to deal with this. But keeping in mind the long duration and late showing off of this side effect long acting 5HT3 acting antagonist were invented like palanosetron. But its high cost made its utility less common, so in order to cut down the cost without comprising on effect adjuvants like dexamethasone were used. Aim: To compare $0.075 \mathrm{mg}$ palanosetron with $0,05 \mathrm{mg}$ palanosetron with $4 \mathrm{mg}$ dexamethasone to prevent post op nausea and vomiting in laproscopic surgeries. Subjects and Methods: This study was a randomised, prospective, trial done on 100 adults, A.S.A. Grade I to II patients, age1865 years going for laparoscopic hysterectomy. They were sent to two groups which got either of the treatment regimens: Palanosetron 75 microgram $(\mathrm{Gr} \mathrm{P}$, number $=50)$ or dexamethasone four milligram plus palanosetron 50 microgram $(\mathrm{Gr} \mathrm{PD}$, number $=50)$. The main outcome was number of PONV cases in 24 hour and the secondary outcome included number of rescue antiemetic required. Student's t test used to analyze normally distributed data. Mann Whitney-U test applied for skewed data. Chi-square / Fisher exact test whatsoever was applicable was applied to Qualitative /categorical variables. All tests done were two-sided and performed keeping a significance level of 0.05 . Results: There was no significant difference in the two groups $(\mathrm{P}>0.05)$ in terms of incidence of nausea, vomiting, retching, patient satisfaction and even side effects. Conclusion: $0.05 \mathrm{mg}$ palanosetron with $4 \mathrm{mg}$ dexamethasone and $0,075 \mathrm{mg}$ Palanosetron are equally effective to prevent post op nausea vomiting plus more cost effective.

Keywords: PONV, Laproscopic, palanosetron, dexamethasone, 5HT3 antagonist, adjuvant.

Corresponding Author: Dr. Payal Jain, Assistant Professor, Department of Anaesthesia, Teerthanker Mahaveer Medical College and research Centre, Moradabad

Received: November 2019

Accepted: November 2019

\section{Introduction}

Post operative nausea and vomiting (PONV) is one of the most distressing outcomes of anaesthesia and surgery having an unaccepatable high number of sufferers. ${ }^{[1]}$ Due to its complex mechanism and casual attitude of patients as well as doctors unknowingly it has highly increased the toll of delay in patient discharge as well as increase in expenses. Unattented PONV leads to the risk of post-operative bleeding, wound dehiscence, gastric aspiration and electrolyte imbalance, increased intracranial pressure, pneumothorax etc. More than that it can lead to heightened experience of pain, disssatisfaction, dysphoria and overall a bad stay for the patient. PONV is defined as nausea/ vomiting occuring in post anesthesia care unit till immediate 24 hours. Laproscopic surgeries have become the choice for every patient as they allow decreased hospital stay, an earlier return to work and normal activities with less pain associated with the smaller incision and less postoperative ileus. ${ }^{[2,3]}$ For instance, in less than one decade of its first trial (Lyon, France in March 1987 by Phillipe Mouret) laproscopic hysterectomies has changed the thinking and operating habits of surgeons as widely and rapidly like nothing before that it has now emerged as the gold standard treatment for uterus removal. However, postoperative nausea and vomiting (PONV) is among the most common distressing side effects associated with it. The incidence of PONV after LH ranges from $53 \%$ to $72 \%$ according to operative, anaesthetic and patient-related risk factors. ${ }^{[4]}$ Thus the increasing demand for laproscopic surgeries by the patients makes the problem of PONV more important to be dealt with more newer drugs and modalities which are not only patient free but also patient pocket friendly. 
Pathophysiology of PONV is complex, a review has suggested that multiple risk factors such as age, female gender, obesity, nonsmoking status, history of motion sickness, inhalational anesthetics, duration of surgery, and anesthesia contribute to the incidence of PONV. Various receptors on which antiemetics act are cholinergic (muscarinic), dopaminergic (D2), histaminergic (H1), and serotonergic (5-hydroxytryptamine type 3 [5-HT3]) receptors. A commendable development done was the introduction of palanosetron in the the 5-HT3 receptor antagonist group); a promising longer-acting agent having plasma half-life of approximately $40 \mathrm{~h}$ and a much higher binding affinity for the 5-HT3 receptor compared to other "setrons"5. Recent work done using this drug concluded that palonosetron has a unique action to promote the long-term internalization of 5-HT3 receptors in neurons and to decrease the actions of substance $\mathrm{P}$ on NK1receptors, likely by indirect mechanisms. Therefore, the dose was increased to $7.5 \mu \mathrm{g} / \mathrm{kg}$, as efficacy of palanosetron is dose dependent thus hypothesising that this higher dose could further decrease the rate of PONV. But, since palonosetron is quite expensive (138 Rs./25 microg), increase in dose of palanosetron can result in an increased expenses for patients. Multimodal antiemetic therapy is well know for being more effective for treating PONV. ${ }^{[6,7]}$ Thus, we combined dexamethasone whose prevention of arachidonic acid release and synthesis of certain inflammatory agents that sensitize nerves that control emesis. Therefore, it was hypothesized that multimodal therapy could achieve equivalent efficacy and cost less compared with monotherapy using a higher dose of palanosetron. In addition to this, studies also suggest that glucocorticoids actually have a direct inhibitory effect on 5HT3 receptors 8, which explains their additive effect when combined with use of 5-HT3 receptor antagonists. Society for Ambulatory Anesthesia (SAMBA) guidelines recommends $4 \mathrm{mg}$ dose as monotherapy or in combination to any other drug to prevent post op nausea and vomiting. The cost of one ampoule of dexa is Rs.4.23/4mg. Thus, if we combined 50 microgm of palanosetron with dexamethasone this made the treatment much more cost effective. Studies conducted on palanosetron with adjuvants9 have concluded that combining two drugs not only increases the duration of action of palanosetron but decreases rescue antiemetics and gives better patient satisfaction score. No study so far as compared low dose palanosetron with dexamethasone with high dose palanosetron. Thus we took up this combination to study the effects of these drugs on each other.

\section{AIM and OBJECTIVES}

AIM- To study comparison between $0.075 \mathrm{mg}$ palanosetron with $0.05 \mathrm{mg}$ palanosetron with $4 \mathrm{mg}$ dexamethasone as adjuvant to prevent post-operative nausea and vomiting

\section{Objectives-}

1) To count incidence of nausea and vomiting at $30 \mathrm{~min}, 2$, $8,24,36,48 \mathrm{~h}$ using four point scoring system

2) To study patient satisfaction score.

3) To calculate total dose of rescue antiemetics required.

4) To study any side effects of drugs used.

\section{Subjects and Methods}

After ethical approval from the institute and informed consent from patients, we studied 100 patients. Inclusion criteria - American Society of Anesthesiologists (ASA) physical Status I and II patients, aged 18 to 65 years, weighing 40-80 kg, scheduled for elective laparoscopic hysterectomy under GA. The study was a prospective, randomized, double-blind study.

\section{Exclusion criteria were-}

1) Pregnancy,

2) Gastrointestinal or renal disease,

3) Who received cancer chemotherapy within past four weeks, emetogenic radiotherapy within past eight weeks,

4) Who had experienced motion sickness

5) H/o epilepsy,cardiovascular compromise

6) Anti-emetic medication within $24 \mathrm{~h}$ before surgery, were excluded from the study.

The patients were randomly distributed using computer generated numbers enclosed within a chit into two groups $\mathrm{P}$ and PD.

Group P patients received $0.075 \mathrm{mg}$ palonosetron

Group PD received a combination of $0.05 \mathrm{mg}$ palonosetron with $4 \mathrm{mg}$ dexamethasone.

One doctor, who was not part of the study, prepared the drugs in identical $20 \mathrm{ml}$ syringes, containing either $0.075 \mathrm{mg}$ palonosetron or $0.05 \mathrm{mg}$ palonosetron and $4 \mathrm{mg}$ dexamethasone (total volume of $20 \mathrm{ml}$ made with normal saline). The study drugs were known already to be compatible when mixed and administered just before induction of anesthesia.

A senior anesthesiologist who gave general anesthesia and used the study drug, was not aware of the type of study drug used and did not participate in the study.

A standardised protocol followed in the institute for general anesthesia was done in all the patients.

Fasting observed for 8 hours.

\section{Premedication}

Inj.Midazolam $1.5 \mathrm{mg}$,

Inj.glycopyrolate $0.2 \mathrm{mg}$, and

Inj.fentanyl $2 \mathrm{mcg} / \mathrm{kg}$ given by intravenous (IV) route, before start of the anesthetic procedure.

Monitoring - pulse rate, non-invasive blood pressure, electrocardiography ECG, oxygen saturation, and end-tidal carbon dioxide (ET CO2)

The study drugs were given slow IV, just before induction of anesthesia.

Patients were pre-oxygenated with oxygen for $3 \mathrm{~min}$,

Induction - IV Propofol $1.5 \mathrm{mg} / \mathrm{kg}$, followed by IV vecuronium $0.08 \mathrm{mg} / \mathrm{kg}$ and direct laryngoscopy with intubation by endo-tracheal tube of appropriate size.

Oro-gastric tube was introduced after intubation and suction through tube was done.

Maintenance- $33 \%$ oxygen with nitrous oxide with $0.5-1.5 \%$ isoflurane and 8 liters of total gas flow.

Inj vecuronium was repeated at $0.01 \mathrm{mg} / \mathrm{kg}$ and Inj fentanyl 1 $\mathrm{mcg} / \mathrm{kg}$ at 30 -min interval. 
Controlled - Ventilation was done to maintain ET CO2 at 30$35 \mathrm{~mm} \mathrm{Hg}$. Intra-abdominal pressure was maintained below $15 \mathrm{~mm} \mathrm{Hg}$.

Analgesia - Inj tramadol $100 \mathrm{mg}$ IV was given to all patients, 30 min before the end of surgery.

At finish of the operation, residual neuromuscular blockade was antagonized with Inj neostigmine $0.05 \mathrm{mg} / \mathrm{kg}$ with glycopyrolate $(0.2 \mathrm{mg}$ for each $1 \mathrm{mg}$ of neostigmine).

After suctioning of the oropharynx and adequate recovery from GA as per clinical observation extubation was done . Patient conscious,oriented and responding was sent to post anaesthesia care unit (PACU) and oxygen was administered at $3 \mathrm{l} / \mathrm{min}$. There was provision of rescue analgesic in the form of IV paracetamol $1 \mathrm{~g}(100 \mathrm{ml})$.

Patients were inquired about nausea, vomiting, retching and any side-effects, at 30min, 2, 8, 24, 36, $48 \mathrm{~h}$ by an investigator; who was blinded to the study.

PONV measurement scale-was measured on a four-point (14) scoring system.

Score 1 = no nausea /retching;

$2=$ complaining of nausea/ retching;

$3=$ vomiting less than two times in $30 \mathrm{~min}$;

$4=$ vomiting more than an two times in $30 \mathrm{~min}$.

Nausea was characterised as - unpleasant sensation characterized by gastrointestinal distress and an urge to vomit.

Retching was defined as the labored, spastic, rhythmic contraction of the respiratory muscles without the expulsion of the gastric contents.

Vomiting was defined as the forceful expulsion of gastric contents from the mouth. The number of patients in each category were recorded. If PONV score was 2 or more, IV ondansetron $4 \mathrm{mg}$ was given as rescue anti-emetic.

Any need for rescue drug and side-effects like headache, dizziness and drowsiness were noted.

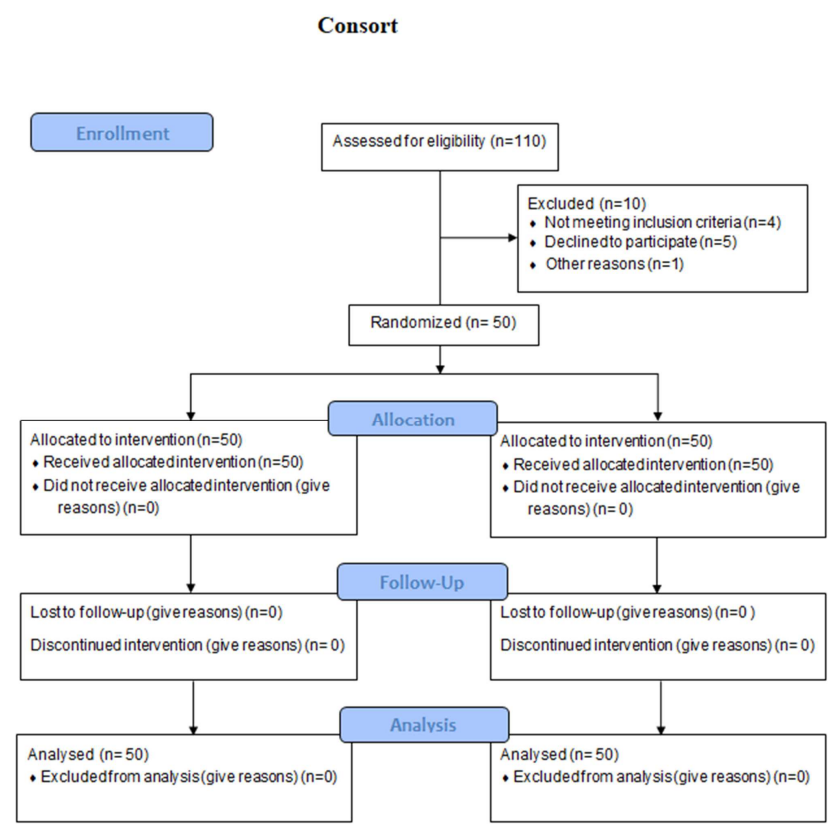

The statistical analysis was performed with the SPSS 15.0 software. All quantitative variables were estimated using measures of central location and measures of dispersion. The normally distributed data were compared using Student's t test. For comparison of skewed data Mann Whitney-U test was applied. Qualitative or categorical variables were described as frequencies and compared with Chi-square or Fisher exact test whichever was applicable. All statistical tests were two-sided and were performed at a significance level of 0.05. Sample size was calculated on the basis of previous studies presuming at least $25 \%$ difference in the incidence of postoperative vomiting between groups, with $\alpha=0.05$ and $\beta=0.80$ showed that 42 patients were required in each group. Thus, we took 50 patients in both group to take into account drop outs.

\section{Results}

Table 1: Demographic data and intraoperative data.

Table 1: Demographic data and intraoperative data.
\begin{tabular}{|l|l|l|l|}
\hline Parameter & Group P & Group pD & P value \\
\hline Age(yr) & $41.06+10$ & $40.84+12$ & 0.006 \\
\hline Gender (M:F) & $10: 40$ & $12: 38$ & 0.128 \\
\hline Weight(kg) & $63.02 \pm 11.70$ & $59.67 \pm 7.05$ & 0.009 \\
\hline Height(cm) & $158.40 \pm 3.46$ & $160.02 \pm 4.69$ & 0.101 \\
\hline ASA Grade & $34: 16$ & $40: 10$ & 0.201 \\
\hline $\begin{array}{l}\text { Duration of } \\
\text { surgery(mins) }\end{array}$ & $68.33 \pm 12.30$ & $63.49 \pm 15.79$ & 0.007 \\
\hline $\begin{array}{l}\text { Durationof CO2 } \\
\text { insufflation (min) }\end{array}$ & $55.50 \pm 11.01$ & $56.52 \pm 14.2$ & 0.014 \\
\hline
\end{tabular}

Table 2: Comparison of incidence of post operative nausea and vomiting among the two groups.

\begin{tabular}{|l|l|l|l|}
\hline Parameter & Group P (50) & $\begin{array}{l}\text { Group pD } \\
(\mathbf{5 0 )}\end{array}$ & P value \\
\hline $\begin{array}{l}\text { PONV } \\
\text { Immediately }\end{array}$ & & & \\
\hline 1 & $45(90 \%)$ & $43(86 \%)$ & 0.008 \\
\hline 2 & $3(6 \%)$ & $5(10 \%)$ & 0.129 \\
\hline 3 & $1(2 \%)$ & $1(2 \%)$ & 0.012 \\
\hline 4 & $1(2 \%)$ & $1(2 \%)$ & 0.012 \\
\hline PONV 30min & & & \\
\hline 1 & $48(96 \%)$ & $46(92 \%)$ & 0.041 \\
\hline 2 & $2(4 \%)$ & $2(4 \%)$ & 0.028 \\
\hline 3 & 0 & $1(2 \%)$ & 0.012 \\
\hline 4 & 0 & $1(2 \%)$ & 0.012 \\
\hline PONV 2hr & & & \\
\hline 1 & $49(98 \%)$ & $48(96 \%)$ & 0.045 \\
\hline 2 & $1(2 \%)$ & $1(2 \%)$ & 0.012 \\
\hline 3 & 0 & $1(2 \%)$ & 0.033 \\
\hline 4 & 0 & 0 & \\
\hline PONV 4hr & & & \\
\hline 1 & $50(100 \%)$ & $49(98 \%)$ & 0.046 \\
\hline 2 & 0 & $1(2 \%)$ & 0.012 \\
\hline 3 & 0 & 0 & \\
\hline 4 & 0 & 0 & \\
\hline PONV 8hr & & & \\
\hline 1 & $49(98 \%)$ & $48(96 \%)$ & 0.045 \\
\hline 2 & $1(2 \%)$ & $1(2 \%)$ & 0.012 \\
\hline 3 & 0 & $1(2 \%)$ & 0.033 \\
\hline 4 & 0 & 0 & \\
\hline PONV 16hr & & & 0.014 \\
\hline 1 & $46(92 \%)$ & $47(94 \%)$ & 0.026 \\
\hline 2 & $3(6 \%)$ & $2(4 \%)$ & 0.007 \\
\hline 3 & $1(2 \%)$ & $1(2 \%)$ & 0.012 \\
\hline 4 & 0 & 0 & 0.032 \\
\hline PONV 32hr & & $44(88 \%)$ & \\
\hline 1 & $43(86 \%)$ & $3(6 \%)$ & \\
\hline 2 & $3(6 \%)$ & $2(4 \%)$ & \\
\hline 3 & $3(6 \%)$ & $1(2 \%)$ & \\
\hline 4 & $1(2 \%)$ & & \\
\hline PONV 48hr & & & \\
\hline
\end{tabular}




\begin{tabular}{|l|l|l|l|}
\hline 0 & $44(88 \%)$ & $45(90 \%)$ & 0.045 \\
\hline 1 & $3(6 \%)$ & $3(6 \%)$ & 0.032 \\
\hline 3 & $3(6 \%)$ & $2(4 \%)$ & 0.007 \\
\hline 4 & 0 & 0 & \\
\hline
\end{tabular}

There was no significant difference between the two groups with respect to age, height, weight, PONV risk factors and ASA status. Groups were well matched in duration of surgery and $\mathrm{CO} 2$ insufflation time. On table fluid given and hemodynamic parameters were also comparable. There was no significant difference between incidence of post op nausea and vomiting between the two groups as shown in [Table 2]. Age, gender when taken as risk factors also showed no significance change between the two groups. Rescue antiemetic required was also comparable. [Table 3]. Rescue analgesic requirement in group $\mathrm{pD}$ was less than group P.

Side effects of headache and palpitations was noted in three patients in group $\mathrm{P}$ and one patient in group $\mathrm{pD}$ but is attributed to over anxious personality .Hence, High dose $0.075 \mathrm{mg}$ palano and low dose palano plus dexa showed similar efficiency in prevention of post op nausea and vomiting.

Table 3: Comparison between confounding factors for PONV and use of rescue antiemetics as well analgesics.

\begin{tabular}{|l|l|l|l|}
\hline Parameters(PONV) & Group P & Group pD & P value \\
\hline Age<60yrs & $4(45)$ & $6(48)$ & 0.076 \\
\hline Age>60yrs & $3(5)$ & $1(2)$ & 0.089 \\
\hline Male & $2(10)$ & $1(5)$ & 0.068 \\
\hline Female in & $5(40)$ & $6(45)$ & 0.097 \\
\hline $\begin{array}{l}\text { Rescue antiemetics } \\
\text { 48hrs }\end{array}$ & 10 & 12 & 0.065 \\
\hline Analgesic use & 40 & 25 & 0.04 \\
\hline Adverse effects & 1 & 2 & 0.09 \\
\hline
\end{tabular}

Table 4: Showing patients satisfaction after both group drug.

\begin{tabular}{|l|l|l|l|}
\hline $\begin{array}{l}\text { Satisfaction } \\
\text { score }\end{array}$ & Group P & Group pD & P value \\
\hline Satisfied & 40 & 38 & 0.074 \\
\hline Neutral & 3 & 5 & 0.082 \\
\hline Not satisfied & 7 & 7 & 0.09 \\
\hline
\end{tabular}

\section{Discussion}

The incidence of PONV in patients undergoing laparoscopic hysterectomy has been reported 53-75\% when no prophylactic antiemetic is provided. ${ }^{[10]}$ The etiology of PONV remains unclear, but is probably due to intraperitoneal $\mathrm{CO} 2$ insufflation leading to stretching and irritation of peritoneum. ${ }^{[1]}$ Palonosetron has higher receptor affinity and more potent binding with 5-HT3 receptors than other 5-HT3 antagonists. In addition, it also has longer half life $(40 \mathrm{~h})$. Furthermore, Palonosetron also exhibits antinauseatic property. ${ }^{[12]}$ The normal dose usually used for palanosetron is $0.075 \mathrm{mg}$ given three times a day, which makes the total expense very high. Thus, taking into consideration the economic condition of our country we tried to add dexamethasone as adjuvant to $0.05 \mathrm{mg}$ to palanosetron and thus compare its effects to high dose palanosetron in order to cut down the cost factor without comprising the effect of drug. Dexamethasone can potentiate the effect of other antiemetics by various mechanisms like, prostaglandin antagonism, release of endorphins and bradykinin reduction. The combination therapy using dexamethasone and 5-HT3 antagonists, ondansetron, granisetron, ramosetron as well as dolasetron, appears to be more effective than single-drug prophylaxis in patients at high risk for PONV. No study has been conducted on low dose versus high dose palanosetron so indirect results from other studies conducted were compared with our study results. In a recent study, the ramosetron and dexamethasone combination was found to be superior to ramosetron alone with $93 \%$ patients showing complete response at 12-24 $\mathrm{h}$ after laparoscopic cholecystectomy in combination group. In one more study 18 $(42.9 \%)$ patients reported nausea and $14(33.3 \%)$ patients had vomiting in group $\mathrm{P}$ while $6(14.4 \%)$ patients had nausea and $5(11.9 \%)$ patients complained of vomiting in group DP during 0-24 h. This is comparable to both our groups where almost $5 \%$ patients experienced nausea and vomiting in both groups.

In study conducted by Chatterjee $\mathrm{A},{ }^{[13]}$ overall incidences of PONV were $23.4 \%$ in PD, $27.2 \%$ in $\mathrm{P}$ and $56.14 \%$ in D group in $24 \mathrm{~h}$ postoperatively. Similarly in our study there was no significant difference in PONV in both groups with low dose palanosetron with dexamethasone as well high dose palanosetron (At 16 hrs $8 \%$ complained of PONV in group P and $6 \%$ in group $\mathrm{pD}$ ). In the study conducted by BALA I et $\mathrm{al}^{[14]} 33.3 \%$ patients receiving only palanosetron experienced vomiting during $0-24 \mathrm{~h}$ while $11.9 \%$ patients in palanosetron- dexamethasone combination group. Similar results were seen in both our groups showing no significant difference between the two groups thus showing efficacy and full fleged use of dexamethasone along with low dose palanosetron. Moreover, Addition of dexamethasone to palanosetron also reduced the requirement of rescue antiemetic medication and was associated with greater patient satisfaction. Study by Park et al15 comparing palanosetron with palanosetron and dexamethasone $4 \mathrm{mg}$ combination in gynaecological laparoscopic procedures reported no significant difference in PONV among groups. The incidence of PONV was $9.8 \%$ and $14 \%$ in palanosetron and combination group respectively. Blitz et al.16 compared $0.075 \mathrm{mg}$ palanosetron and $8 \mathrm{mg}$ dexamethasone combination therapy with palanosetron monotherapy in patients undergoing outpatient laparoscopic surgeries and reported low incidence of PONV in both the groups (Pal+Dex, 1.7\%; Pal, 6.8\%) with no increase in side effects profile due to use of $8 \mathrm{mg}$ dexamethasone. Our patients were at high risk for PONV due to non-smoking habits, female gender and laparoscopic surgery. Though, all these factors were well balanced among the groups. There were no severe adverse effects in any group of patients in our study. Moreover, the use of rescue analgesia was also comparable in both the groups. Patient in both groups were equally satisfied. One positive finding we found in our study was that patients given dexamethasone needed less use of rescue analgesics than patients not receiving it which may be due to its anti-inflammatory action.

\section{Conclusion}

As both the groups one receiving $0.075 \mathrm{mg}$ palanosetron and 
other using $0.05 \mathrm{mg}$ palanosetron plus $4 \mathrm{mg}$ dexamethasone had similar effects thus addition of adjuvant to low dose of palanosetron cuts down the cost three times but leads to no compromise on patients comfort as well as no adverse effect.

\section{References}

1. Halliday TA, Sundqvist J, Hultin M, Walldén J. Post $\square$ operative nausea and vomiting in bariatric surgery patients: An observational study. Acta Anaesthesiol Scand 2017;61:471 $\square$ 9.

2. Bremner WG, Kumar CM. Delayed surgical emphysema, pneumomediastinum and bilateral pneumothoraces after postoperative vomiting. Br J Anaesth 1993;71:296ロ7.

3. Schumann R, Polaner DM. Massive subcutaneous emphysema and sudden airway compromise after postoperative vomiting. Anesth Analg 1999;89:796 $\square 7$.

4. Larsson S, Lundberg D. A prospective survey of postoperative nausea and vomiting with special regard to incidence and relations to patient characteristics, anesthetic routines and surgical procedures. Acta Anaesthesiol Scand 1995;39:539 $\square 45$.

5. Ho KY, Gan TJ. Pharmacology, pharmacogenetics, and clinical efficacy of $5 \square$ hydroxytryptamine type 3 receptor antagonists for postoperative nausea and vomiting. Curr Opin Anaesthesiol 2006;19:606 $\square 11$.

6. Dabbous AS, Jabbour-Khoury SI, Nasr VG, Moussa AA, Zbeidy RA, Khouzam NE et al. Dexamethasone with either granisetron or ondansetron for postoperative nausea and vomiting in laparoscopic surgery. Middle East J Anesthesiol 2010;20:565-70.

7. Jo YY, Lee JW, Shim JK, Lee WK, Choi YS. Ramosetron, dexamethasone, and their combination for the prevention of postoperative nausea and vomiting in women undergoing laparoscopic cholecystectomy. Surg Endosc 2012;26:2306- 11.

8. Piper SN, Triem JG, Rohm KD, Kranke P, Maleck WH, Boldt J.
Prevention of post-operative nausea and vomiting. Randomised comparison of dolasetron versus dolasetron plus dexamethasone. Anaesthesist 2003;52:120-6.

9. Feo CV, Sortini D, Ragazzi R, De Palma M, Liboni A. Randomized clinical trial of the effect of preoperative dexamethasone on nausea and vomiting after laparoscopic cholecystectomy.Br J Surg 2006;93:295-9.

10. McKenzie R, Tantisira B, Karambelkar DJ, Riley TJ, Abdelhady H. Comparison of ondansetron with ondansetron plus dexamethasone in prevention of postoperative nausea vomiting. Anesth Analg 1994;79:961-4.

11. Maharaj CH, Kallam SR, Malik A, Hassett P, Grady D, Laffey JG. Preoperative intravenous fluid therapy decreases postoperative nausea and pain in high risk patients. Anesth Analg 2005;100:675-82.

12. Rojas C, Stathis M, Thomas A, Massuda E, Alt J, Zhang J, et al. Palonosetron exhibits unique molecular interactions with the 5-HT3 receptor. Anesth Analg 2008:107:469-78.

13. Chatterjee S,Rudra A, Sengupta S.Current concepts in the management of postoperative nausea and vomiting.Anesthesiol Res Pract.2011;2011:748031.doi:10.1155/2011/748031.Epub 2011 Nov 3.

14. Bala I, Bharti N, Murugesan S, Gupta R. Comparison of palanosetron with palanosetron -dexamethasone combination for prevention of postoperative nausea and vomiting in patients undergoing laproscopic cholecystectomy.Minerva Anestesiol.2014;80:779-84.

15. Park JW ,Jun JW, Lim YH, Lee SS, Yoo BH, Kim KM, et al.The comparative study to evaluate the effect of palanosetron monotherapy versus palanosetron with dexamethasone combination therapy for prevention of postoperative nausea and vomting.Korean $\mathrm{J}$ Anesthesiol.2012;63:334-39.

16. Blitz JD, Haile M, Kline R, Franco L, Didehvar S, Pachter HL, et al.A randomised double blind study to evaluate efficacy of palanosetron with dexamethasone versus palanosetron alone for prevention of postoperative and postdischarge nausea and vomiting in subjects undergoing laproscopic surgeries with emetogenic risk.Am J Ther.2012;19:324-29.

Copyright: () the author(s), publisher. Academia Anesthesiologica International is an Official Publication of "Society for Health Care \& Research Development". It is an open-access article distributed under the terms of the Creative Commons Attribution Non-Commercial License, which permits unrestricted non-commercial use, distribution, and reproduction in any medium, provided the original work is properly cited.

How to cite this article: Jain P, Ahluwalia P, Ahluwalia A, Jain R. Study Comparing High Dose Palanosetron 0.075mg with Low Dose Palanosetron $0.05 \mathrm{mg}$ Plus $4 \mathrm{mg}$ Dexamethasone as Adjuvant for Prevention of Post-Operative Nausea and Vomiting in Laproscopic Hysterectomies - A Double Blinded Study. Acad. Anesthesiol. Int. 2019;4(2):271-5.

DOI: dx.doi.org/10.21276/aan.2019.4.2.61

Source of Support: Nil, Conflict of Interest: None declared. 